\title{
WALT WHITMAN, LITERARY CULTURE, AND THE DISCOURSE OF DISTINCTION
}

\author{
CHRISTOPHER BEACH
}

DesPite the undeniable importance of literary intertexts in Whitman's poetic works, it has been well established by recent critics that Whitman's poems and nonpoetic writings radically subvert his era's notions of cultural tradition and literary decorum on thematic, discursive and stylistic levels. ${ }^{1}$ Pierre Bourdieu describes a similar subversion to that which Whitman practices when he uses the poems of Leaves of Grass to challenge the prevailing cultural codes of nineteenth-century America. Bourdieu theorizes the way in which a radical "carnivalization" of past literary modes and genres by the heteroglossic positioning of those older forms within the modern text can lead to the fragmentation and subversion of literary formulas, especially those involving "high [cultural] positions and symbols." "In Bourdieu's cultural critique, a writer like Rabelais appears as a "counter-artist": a writer who will invert all culturally-sanctioned aesthetic forms in order to establish a new cultural order which flouts the very signs of "distinction" on which the dominant culture rests.

Whitman incarnates in the nineteenth century Bourdieu's "counter-artist" when he uses the poem as a means of celebrating the body, thereby establishing a classless and "natural" order in opposition to the dominant cultural regime and its associated literary canon. Like Rabelais, Whitman will at times reverse the aesthetic sublimation of popular desires by subverting the values in which the dominant groups assert their sublimity; his rhetoric of the democratic en masse appears to overthrow, or at least to circumvent, more conventional societal and poetic attempts at cultural distinction. Whitman's progression from journalism to poetry, a form of writing which foregrounds its intertextual and its aesthetic status in a way that traditional journalism does not, also forced him to rethink the status of literary writing, to subvert the aesthetic distinction inherent in an intertextual practice by privileging aspects of discourse and experience that such literary intertexts ignore.

Rather than evoking the carnivalesque pleasures which form the popular imagination of Rabelaisian culture, Whitman articulates his questioning of cultural values in terms of a more earnestly American argument with dominant European sociocultural structures and institutions. ${ }^{3}$ Whitman attacks the class system on which he believes the European notion of "literature" to have been founded; he argues that 
the purpose of literary writing has always been "to magnify and intensify its own technism, to isolate itself from general and vulgar life, and to make a caste or order" of the highly literate. ${ }^{4}$ For Whitman, a culturally elitist literature that rejects the "vulgarity" of everyday life implies a concomitant embrace of hierarchical, even monarchic political exclusivity. Whitman's democratic "language experiment," his destruction of the boundaries between self and other, and his designation of the physical body as a figure for inherent social dynamics, all suggest a privileging of identification over difference that is consistent with Bourdieu's definition of "popular" cultural forms. Whitman's poetic is predicated on equality rather than class distinction, on participation rather than exclusion, and on biological standards rather than sociocultural ones.

Whitman's own relationship to the literary, and more particularly the poetic, canon appears to have gone through three fairly distinct phases. In the 1840 s and early 1850 s, he expresses approval of the Romantic canon; he praises Wordsworth, Keats, Byron, and Burns, as well as American contemporaries like Emerson, Bryant, and Longfellow. In a second phase, spanning from the mid to late $1850 \mathrm{~s}$, Whitman appears to reject all poetic models, including most noticeably his poetic "master" Emerson. Hints of Whitman's dissatisfaction with the literary canon can be found beginning in the early 1850 s, about the time that he began to formulate what would be his distinctive poetic idiolect. In 1851 he criticized Wordsworth's poem "To My Sister" for its Romantic devotion to nature rather than to man, and he accused Bryant of the same tendency. ${ }^{5}$ In a notebook entry from the early 1850 s, he chastised Keats, whom he had praised in 1846 as "one of the pleasantest of modern poets," for his overreliance on classical myth: "Of life in the nineteenth century [Keats's poetry] has none any more than the statues have" (NUPM, 1770). ${ }^{6}$ And in his self-review of the 1855 Leaves of Grass, he claims to have founded a "new school" of poetry that would be independent of all previous models.

Yet despite this apparent rejection of the literary, Whitman never lost interest in the canon itself or in literary history. Several of Whitman's unpublished manuscripts - dating from 1855 until the 1860s - are lists of poets and their dates. These lists reveal a desire to formulate his own sense of a canon of significant writers: they include catalogues of the entire canon of English poets, of contemporary authors (Byron, Hunt, Shelley, Coleridge, Southey, Moore, Campbell, Crabbe, Rogers, Keats, and Wordsworth), of the "New English Poets," including Alexander Smith and Matthew Arnold, and finally of poets from various countries in Western Europe. ${ }^{7}$

After 1860, motivated both by his own commercial failure as a poet and by the traumatic onset of the Civil War, Whitman enters the final 
phase of his engagement with the literary canon, expressing from this point on an ever greater appreciation of the Anglo-American poetic tradition, including even a poet such as Tennyson, for whom he had previously shown relative contempt. The trajectory of Whitman's opinion of Tennyson exemplifies the more generic trend in his relationship to the literary canon, especially since he considered Tennyson to stand with Shakespeare and Sir Walter Scott as one of the three English authors best known to American readers. After dismissing Tennyson as a "jingler" before the war, Whitman begins to appreciate and even to imitate some of his "verbal melody" $(P W, 477)$ in the post-war period. Whitman initiated a correspondence with Tennyson in 1871 and wrote positive comments on the British poet's work in his notebooks of 1878 ; in 1881 he gave him a mostly favorable, though still reserved, review in the essay "Poetry To-day in America-Shakespeare-The Future," and by 1887 he had further revised his opinion in a positive direction, making the curious comment in "A Word About Tennyson" that although he still finds him undemocratic, he "like[s] him the better for it." Whitman's praise of Tennyson's work and character is full of superlatives: the English poet displays the "finest verbalism" and a "superb character." Tennyson's faults have been converted into virtues: his mannerisms are "noble and welcome," and his moral stance, conventional as it is, remains "vital and genuine" ( $P W, 570-71)$.

Even Whitman's later writings, however, indicate that, if he was willing to temper the harshness of his opinion of Anglo-American poetic writing, he continued to harbor doubts, especially concerning Emerson and the "fireside" poets. Whitman's critique of his most significant American contemporary, Emerson, reveals a desire to create a straw man against whom he can define his aspirations for American poetry in general, and more specifically reveals his desire to establish in his own work a "popular" poetic form unlike the intellectually elitist writing of Emerson and the Transcendentalists. In 1856, when Whitman still believed in the potential of Leaves of Grass to be a truly "popular" work in his own time, he predicted to Emerson sales of more than twenty thousand copies a year. Fifteen years later, Whitman would realize in Democratic Vistas that if his poetry could not attain anything like that readership in his day, it would ultimately prove popular in another sense: later readers would appreciate its value as a poetry of the people, of the "masses."

Though Whitman claims that he is "not insensible to [Emerson's] deepest lessons," he proceeds in his 1880 article "Emerson's Books, (The Shadows of Them)," to treat Emerson's writings in a disparaging, even dismissive fashion. Emerson "possesses a singularly dandified theory of manners," prefers "verbal polish" and "quaint conceits" to true sublimity, and it is doubtful whether he "really knows or feels what 
Poetry is at its highest, as in the Bible, for instance, or Homer or Shakspere" (PW, 517). We might find the harshness of Whitman's criticism surprising, especially of a man who, as Whitman writes the following year, "stands unmistakably at the head" of American poets $(P W, 267)$. However, the subtext of Whitman's comments is not Emerson but American (high) culture. Beginning his remarks with the observation that Emerson's pages are "too perfect," Whitman launches into a cultural critique both of Emerson's art and of those readers who continue to support its literary status:

And though the author has much to say of freedom and wildness and simplicity and spontaneity, no performance was ever more based on artificial scholarships and decorums at third or fourth removes, (he calls it culture,) and built up from them. It is always a make, never an unconscious growth. It is the porcelain figure or statuette of lion, or stag, or Indian hunter-and a very choice statuette too-appropriate for the rosewood or marble bracket of parlor or library; never the animal itself, or the hunter himself. Indeed, who wants the real animal or hunter? What would that do amid astral and bric-a-brac and tapestry, and ladies and gentlemen talking in subdued tones of Browning and Longfellow and art? The least suspicion of such actual bull, or Indian, or of Nature carrying out itself, would put all those good people to instant terror and flight. (515-516)

Whitman's anti-“cultural" rhetoric is as powerful here as anywhere in his writing. Beginning with a seemingly innocuous criticism of Emerson's work, he proceeds metaphorically to pull the expensive Persian rug out from underneath the entire cultural system of which Emerson is part-a system of "ladies and gentlemen" who exemplify Bourdieu's notion of cultural "distinction" as a "counter-nature" in opposition to corporeal or physical reality. Moreover, the "bric-a-brac," tapestries, and expensive furniture to which Whitman compares Emerson's poems place them in the context of the late nineteenth-century commodity fetishism critiqued by Marx; Emerson's works have crossed the line from art to "kitsch."8

Such a rhetorical tour de force on Whitman's part cannot disguise his interest in the question of poetic "distinction"-one that is clear even from the terms in which he dismisses Emerson. For Whitman, "Poetry at its highest" is exemplified by the Bible and by the works of Homer and Shakespeare, all of which had served as models or intertexts for every Romantic poet, and every English poet since Milton. (Even his capitalization of "Poetry" confers a distinction on poetic writing that separates it from other cultural forms.) Whitman, then, does not reject all forms of aesthetic production, but only the particular form of "culture"-decorous, domesticated, artificial - that he finds exemplified in Emerson.

In a notebook entry from 1872 , Whitman makes the most obvious rhetorical differentiation between two kinds of culture and their attendant literary expressions. Here, Whitman views Emerson as emblematic 
of "Culture" and "Literature" (as opposed to the more democratic "culture" and "literature"). Whitman associates Emerson with American cultural theories that remain "absorbed in interests \& tendencies not those of Democracy," and that have "never cordially accepted the idea of American Personalism, nor earnestly contributed toward it" (NUPM, 1721). He concludes with the powerful formulation that "the highest of literature untrammels us, frees us entirely from Literature" (emphasis added). Whitman's comments might usefully be read in the context of Raymond Williams's observation that the nineteenth century experienced a fundamental change in the categories defining art and the aesthetic. "Literature," which had previously denoted the wider general field of written texts, would come to indicate a more specific field of imaginative or creative writing: "Thus the category which had appeared objective as 'all printed books' . . . now became a necessarily selective and self-defining area . . . not all 'literature' was 'Literature.' "9 Such a change was clearly significant for Whitman: in his own recognition of an essential difference between "literature" and "Literature," Whitman signals his reluctance to enter the more narrow field of cultural production defined by an understanding of aesthetic production and reception as a means of cultural distinction.

Yet despite the strength of his statements against what he viewed as the excesses and elitism of Emersonian Culture, the expression of Whitman's cultural attitudes in his published essays of literary criticism, as well as in his prefaces to the editions of Leaves of Grass, is fraught with an ambiguity and ambivalence concerning his own authorial bind within the double logic of distinction: Whitman wants distinction from the culturally distinguished, yet still requires distinction from popular culture and journalistic discourse. Whitman does make the celebratedly democratic assertion that "to have great poets, there must be great audiences too," but he is not willing to dispense with the category of poetic "greatness." In an essay on Shakespeare, Whitman cites as the most "distinctive" poems those which are "the most permanently rooted" - namely, those of the European epic traditions from Homer to the Renaissance. Elsewhere he evaluates poetry according to a hierarchical system of "classes" ("first class," "second class," even "third or fourth class"), claiming that truly "first class" poems include only "a score or two, perhaps less, of typical, primal, representative works, different from any before, and embodying in themselves their own main laws and reasons for being" ( $P W, 539)$. Unlike works of the "second class" which are only "offshoots" or "more or less imitations of the first," first class works are undeniably distinct from other forms of literary production: they make their own laws and are "amenable" only to those same laws. Whitman's rhetoric takes on culturally elitist overtones when he echoes the "sharp warning" of Margaret Fuller: "It does 
not follow that because the United States print and read more books, magazines, and newspapers than all the rest of the world, that they really have, therefore, a literature" ( $P W, 521)$. Whitman's admonition, printed in the 1882 Specimen Days $\mathcal{E}$ Collect, contradicts or at least interrogates his own contention that the size of the American readership alone would guarantee a fruitful poetic future.

What Whitman posits in these writings is nothing less than a theory of literary distinction. As in Bourdieu's paradigm, Whitman is torn between the impulse toward the celebration of popularity and the equally strong impulse toward the sanctification of cultural rarity. Bourdieu maintains that this "dual discourse" of cultural affiliation is present to some degree in the work of any writer: "Intellectuals and artists are thus divided between their interest in cultural proselytism ... and concern for cultural distinction, the only objective basis of their rarity," he states. "Their relationship to everything concerned with the "democratization of culture' is marked by a deep ambivalence which may be manifested in a dual discourse on the relations between the institutions of cultural diffusion and the public." Clearly, the circumstances confronting an American poet of the mid-nineteenth century were very different from those Bourdieu envisions for the French writer. Whitman's choice is not simply between popularity on one hand and elitism on the other; to a large extent Whitman's radicalism (and thus his cultural rarity) is defined precisely in terms of his democratization of what he perceived as culturally elitist tendencies in Romantic poetic discourse. Whitman's intended audience was nothing less than all of America (or at least his idea of all of America), and thus he would have had highly ambivalent feelings about the role of "institutions of cultural diffusion" in determining a particular stratum of the available readership for his work. Yet such objections are not sufficient to negate the validity of Bourdieu's claims. Bourdieu's notion of "distinction" as a polarizing force in all artistic and literary activity throws into relief a fundamental gesture in Whitman's poetics: an ambivalence concerning distinction on both a sociocultural and a poetic level.

In an undated notebook entry from the 1860 s or 1870 s, Whitman describes the poetic function in the elitist and neo-Romantic terms that begin increasingly to punctuate the rhetoric of his later writings. The poet builds an "impregnable and lofty tower ... overlooking all-the citadel of the primary volitions, the soul, the ever-reserved right of a deathless Individuality - and these he occupies and dwells, and thence makes observations and issues verdicts" (NUPM, 1575). Ironically, given his democratic rhetoric, the problem of establishing a "first-class" national poetry in America was a dominant, even obsessive preoccupation for Whitman. As late as 1891, in an essay with the provocative title "American National Literature: Is there any such thing-or can there 
ever be?," Whitman concludes that "the United States do not so far utter poetry, first-rate literature, or any of the so-call'd arts, to any lofty admiration or advantage - are not dominated or penetrated from actual inherence or plain bent to the said poetry or arts" (PW, 668). When Whitman does speak about an important American literature, it is almost invariably with reference to the future.

Whitman's 1881 "tribute" to the American poets Emerson, Longfellow, Bryant and Whittier, published in Specimen Days, represents the poet's defensive attempt to stave off criticism of what were seen as his own contemptuous attitudes toward his contemporaries, rather than a completely sincere comment on the quality of American poetic writing. ${ }^{10}$ Even here, Whitman uses his words carefully. $\mathrm{He}$ refers to his contemporaries as a "mighty four" but never uses the epithets "great" or "first-class"; he claims them as an important "poetical beginning and initiation," not as a finished product of any lasting literary value. Whitman's rhetoric of somewhat muted praise, itself an attempt to atone for past arrogance, still leaves open the possibility of his own work being the first distinctly American poetic project, the first "autochthonic song" of the United States. Here, as throughout Whitman's writings, we find implicit the conflicting desires both to overthrow "culture" defined as refinement and prestige, and to pursue a high cultural mode; he seeks a "first-class" aesthetic project in the service of an undifferentiated populace. From the 1855 preface on, Whitman attempts to separate literary distinction from class distinction, aesthetic refinement from social elitism. But to maintain such a separation in anything other than a rhetorical sense is an untenable proposition: the cultural capital necessary to achieve one part of the equation to a large degree establishes the other.

The essay Democratic Vistas of 1871 defines more thoroughly the "programme of culture" he had already begun to articulate in the 1855 preface. Both Betsy Erkkila and Alan Trachtenberg have contrasted Whitman's cultural manifesto with its British counterpart, Matthew Arnold's Culture and Anarchy of two years earlier. ${ }^{11}$ Whitman's alternative to Arnold's "sweetness and light" appears to be a representation of the democratic state marked by "perfect equality" (the "averaging" of the people). His vision of culture would extend to all social classes, all occupations, all geographical areas, both sexes, and, at least at times, all racial and ethnic groups:

I should demand a programme of culture, drawn out, not for a single class, alone, or for the parlor or lecture-rooms, but with an eye to practical life, the west, the working-men, the facts of farms and jack-planes and engineers, and of the broad range of the women also of the middle and working strata. . . . (PW, 396) 
Whitman rejects the process by which "high culture" is usually determined-"gather, trim, conform . . . and be genteel and proper" (394) - and replaces it with a process of empirical observation and re-statement "in terms consistent with the institution of these states" (425).

By the time of Thorstein Veblen's turn-of-the-century sociological study Theory of the Leisure Class, a sense of economic, social and cultural class divisions was so crystallized in the American mind as to make possible the theoretical discussion of sociocultural "distinction" Veblen provides, one not very different in substance from the categories of distinction more rigorously analyzed by Bourdieu. Veblen anticipates Bourdieu's critique of cultural "taste" by identifying in late nineteenthcentury American society a "leisure-class theory of life" which values antiquated and rarefied forms of culture over practical and modern ones:

The enjoyment and the bent derived from habitual contemplation of the life, ideals, speculations, and methods of consuming time and goods, in vogue among the leisure class of classical antiquity, for instance, is felt to be "higher," "nobler," "worthier," than what results from a like familiarity with the everyday life and the knowledge and aspirations of commonplace humanity in a modern community. That learning the content of which is an unmitigated knowledge of latter-day men and things is by comparison "lower," "base," "ignoble,"-one even hears the epithet "sub-human" applied to this matter-of-fact knowledge of mankind and of everyday. life. ${ }^{12}$

Veblen even goes so far as to theorize those "canons of taste" which are produced by a given race or tradition by "the protracted dominance of a predatory leisure-class scheme of life." Such canons of taste deprecate "matter-of-fact knowledge" and favor what Bourdieu calls "gratuitous" or "free" modes of cultural expression and production. For Veblen, the acquisition of such "disserviceable anachronisms" as ancient languages and the classics not only contributes to the perpetuated mystique of the cultivated classes, but actually "acts to derange the learner's workmanlike aptitudes" and to distance members of the leisure class from the excluded masses. The reification of social class as cultural capital represented by the "useless" knowledge of the classics is analogous, for Veblen, to the conspicuous consumption of expensive or unnecessary material goods. Even the English language, as it is spoken by the upper classes, becomes a tool for cultural distinction; it must be marked as "classic," in both leisure-class conversation and in literary texts, by archaic and excessively elevated diction and by an avoidance of neologisms and practical modes of speech.

Veblen's analysis expresses in more theoretical terms the latent characteristics of American social and cultural life that Whitman already recognized at mid-century. In Democratic Vistas, Whitman performs an analysis of the innate cultural distinction between the "People" on the one hand, and the "merely educated classes," which he aligns with the 
European aristocracy, on the other. In an evocative literary metaphorone that is crucial to my own reading of Leaves of Grass-Whitman compares the less privileged classes to a poem that is ungrammatical and scans roughly:

Like our huge earth itself, which, to ordinary scansion, is full of vulgar contradictions and offence, man, viewed in the lump, displeases, and is a constant puzzle and affront to the merely educated classes. The rare, cosmical, artist-mind, lit with the Infinite, alone confronts his manifold and oceanic qualities-but taste, intelligence and culture, (so-called), have been against the masses, and remain so. . . But the People are ungrammatical, untidy, and their sins gaunt and ill-bred. Literature, strictly considered, has never recognized the People, and, whatever may be said, does not to-day. . . . It seems as if, so far, there were some natural repugnance between a literary and professional life, and the rude rank spirit of the democracies. (PW, 376)

Whitman makes two distinctions here-between the cultured classes and the "People," and between the professional world of letters (where "taste, intelligence and culture" are the highly valued triumvirate) and the "artist-mind" ("rare, cosmical . . . lit with the Infinite") of the true poet, or Whitman himself.

In his "Song of the Exposition," written to commemorate the fortieth annual exhibition of the American Institute in 1871, Whitman provides a poetic illustration of some of Veblen's central ideas, including the commonsensical reminder at the end of Theory of the Leisure Class that "the ideas of to-day are most effectively expressed in the slang of to-day" (400). In his poem, Whitman calls on the Muse to leave behind the works of the past and to join him in "far superber themes": "To exalt the present and the real, / To teach the average man the glory of his daily walk and trade" (202). At the height of his rhetorical zeal, Whitman imagines his Muse in an environment so modern and devoid of poetic decorum that it strains the aesthetic forebearance of even sympathetic readers:

Making directly for this rendezvous, vigorously clearing a path for herself, striding through the confusion,

By thud of machinery and shrill steam-whistle undismay'd,

Bluff'd not a bit by drain-pipe, gasometers, artificial fertilizers,

Smiling and pleased with palpable intent to stay,

She's here, installed amid the kitchen ware! (198)

In terms that would constitute mock-epic in the hands of another poet, Whitman earnestly attempts to present a practical, industrial American landscape as an alternative to the topoi of classical and Romantic poetry. To envision his Muse, borrowed from classical temples and Romantic castles, happily surrounded by chemical fertilizers, kitchen equipment, drainpipes, "gasometers" and thudding machinery, is to eschew all pretense of privilege or refinement as adumbrated by Veblen. Yet 
despite the novelty of its rhetorical message, the poem fails to provide aesthetic balance or power to match its thematic content. Here the juxtaposition of discourses Whitman bravely attempts only overwhelms the aesthetic potential of the poem. The language of religious or transcendental fervor ("exalt," "glory," "superber themes") appears almost gratuitous in the context of the other discourses Whitman privileges: the discourse of activity and physical health ("daily walk and trade," "making directly for this rendezvous," "vigorously clearing a path for herself," "striding," "bluff'd not a bit"), and the discourse of machinery and technological progress, evoked by the hypertechnical terminology of "gasometers."

Whitman proceeds in the next section of the poem to depict the various processes by which physical labor is converted into usable products: cotton into cloth, flour into bread, gold ore into bullion, type into printed pages. Like Veblen, he contrasts these examples of useful, active labor with the wasteful decadence of upper-class "idlers": "The unhealthy pleasures, extravagant dissipations of the few, / With perfumes, heat and wine, beneath the dazzling chandeliers" (202). In rejecting both the epic and the "old romance" as poetic modes of social privilege, Whitman creates for himself the persona through which he is still viewed in the popular imagination: the wild, untutored poet of anti-literary leanings.

Whitman's portrayal of a working-class muse must be read as much as a response to social conditions in his own day as to a literary canon of past works. As Larzer Ziff has indicated, class distinction often went hand in hand with literary distinction in mid-century America, where the wealthy and "gentlemanly" classes held the controls of both literary production and consumption. "In believing they would be the producers as well as the consumers of American literature," Ziff remarks, the upper classes "easily fell into the stuffy notion that literature was not only for the well-bred but could be produced only by the well-bred."13 In The Autocrat of the Breakfast Table, published only three years after the first edition of Leaves of Grass, Oliver Wendell Holmes writes of the creation of an American aristocracy, "a de-facto upper stratum of being, which floats over the turbid waves of common life like the iridescent film you may have seen spreading over the water about our wharves."14 Holmes's commentary prefigures Veblen's caustic critique of the more entrenched leisure class that would evolve by the turn of the century. Money is the basis of this class, Holmes writes, but money is only the beginning:

Money kept for two or three generations transforms a race,-I don't mean in manners and hereditary culture, but in blood and bone. Money buys air and sunshine, in which 
children grow up more kindly, of course, than in back streets; it buys country-places to give them happy and healthy summers, good nursing, good doctoring, and the best cuts of beef and mutton. ... . As the young females of each successive season come on, the finest specimens among them, other things being equal, are apt to attract those who can afford the expensive luxury of beauty. The physical character of the next generation rises in consequence. It is plain that certain families have in this way acquired an elevated type of face and figure . . . which in one or two generations more will be, I think, much more patent than just now.

Holmes presents a vision of a "chryso-artistocracy" which becomes increasingly distinct - both culturally and physically - from the common man and woman, such that any rapprochement between the two groups seems impossible. Holmes's portrait is clearly part of a discourse of class and privilege that finds its inverted form within Whitman's idiolect. In the social analysis of Holmes and Veblen on the one hand, and the poetic vision of Whitman on the other, we find two opposing social trajectories with their attendant discourses: one of increasing privilege and exclusivity (the creation of a socioeconomic and even physiological aristocracy), and one of the democratic "averaging" of all Americans as physical and spiritual equals. ${ }^{15}$ Yet it is significant that these apparently polarized discourses both use as their privileged figure the physical body. Whitman's own interest in the body as register of social distinction was not an isolated one, but part of a larger societal preoccupation with the body as marker of cultural position.

That Whitman was not only aware of such a discourse of distinction as that represented by Holmes, but deeply concerned about its effects, is made clear in an unpublished two-line poem from 1860-61 ("Of My Poems"):

All the others were singing the distinctions, and what was to be preferred.

Therefore I thought I would sing a song of inherent qualities in a man, indifferent

whether they are right or wrong. (680)

"All the others" are presumably those poets writing within the mainstream discourse of cultural privilege defined by Holmes, Dana, Longfellow, Lowell, Emerson and others of their social and educational background. Whitman's brief ars poetica is general enough to cover all the aspects of distinction and preference that he feels are restrictive: social, physical, racial, moral, political, national, geographical, and cultural, as well as literary. The fragment is important both in its rejection of a kind of distinction or preference as a mode of literary discourse, and in its explicit demarcation of Whitman's "I" from "all the others." As such it is a clear indication of how distant-and distinct-Whitman felt from the discourse of other poets writing at mid-century; it was this inverted sense of distinction (a positive render- 
ing of exclusion necessitated by his own lack of cultural capital) that would contribute to the development of a highly distinctive poetic style.

\section{University of Montana}

\section{NOTES}

1 See for example the following books: Betsy Erkkila, Whitman the Political Poet (New York: Oxford University Press, 1989); Byrne Fone, Masculine Landscapes: Walt Whitman and the Homoerotic Text (Carbondale: Southern Illinois University Press, 1992); M. Jimmie Killingsworth, Whitman's Poetry of the Body: Sexuality, Politics, and the Text (Chapel Hill: University of North Carolina Press, 1989); Michael Moon, Disseminating Whitman: Revision and Corporeality in "Leaves of Grass" (Cambridge: Harvard University Press, 1991); Tenney Nathanson, Whitman's Presence: Body, Voice and Writing in "Leaves of Grass" (New York: New York University Press, 1992); and David Reynolds, Beneath the American Renaissance: The Subversive Imagination in the Age of Emerson and Melville (New York: Knopf, 1988).

2 Distinction: A Social Critique of the Fudgement of Taste, trans. Richard Nice (Cambridge: Harvard University Press, 1984), 408.

3 David Reynolds's analysis suggests that aspects of the carnivalesque may in fact exist in Whitman's stance, particularly in his use of the "b'hoy" motif to define his own stance of "independent loafer" and "rowdy mystic" (Beneath the American Renaissance, 465-66). Whitman had clearly read Rabelais and may have been directly influenced by his version of the carnivalesque: he specifically mentions Rabelais among the great writers of "Democracy and Nature," along with Juvenal, Cervantes, and the Hebrew prophet. Whitman mentions Rabelais on two other significant occasions, once citing him as a writer who would have appreciated the vitality of the Broadway omnibus-drivers, and once listing him as one of the "four mighty and primal hands" who would be capable of composing a portrait of President Lincoln. Thus for Whitman, Rabelais appears to stand as one of the central emblems of "democratic" writing.

4 Richard M. Bucke et al., eds. Complete Writings (New York: Putnam, 1902), 9:35-36. Also quoted in Erkkila, Whitman the Political Poet, 76.

5 See Kenneth Price, Whitman and Tradition: The Poet in His Century (New Haven: Yale University Press, 1991), 20.

6 Throughout this essay, I have cited Whitman's works by their abbreviated titles: Leaves of Grass: Comprehensive Reader's Edition (LG), Notebooks and Unpublished Prose Manuscripts (NUPM), and Prose Works 1892 (PW). All references are to volumes contained in The Collected Writings of Walt Whitman (New York: New York University Press, 1965-1984).

7 See NUPM, 1773-76, 1797, and 1799.

8 For an interesting discussion of British material culture that could be usefully applied to American culture of the period as well, see Tom Richards, The Commodity Culture of Victorian England: Advertising and Spectacle 1851-1914 (Stanford University Press, 1990), especially Chapter 1, "The Great Exhibition of Things."

9 Marxism and Literature (Oxford: Oxford University Press, 1977), 51.

10 A more honest statement of his opinion of these writers may be found in anonymous interviews of the period (in the St. Louis Post-Dispatch on October 17, 1879, and the 
London Advertiser [Ontario, Canada] on June 5, 1880; both reprinted in Joel Myerson, ed., Whitman in His Own Time: A Biographical Chronicle of His Life, Drawn From Recollections, Memoirs, Interviews by His Friends and Associates (Detroit: Omnigraphics, 1991). Speaking in a less official capacity, Whitman is more direct (and generally more negative) about the relative strengths and weaknesses of the "mighty four": "Our greatest man is Emerson. Bryant, I think, has a few pulsations. Whittier is a puritan poet without unction-without justice. I hardly know what to say about Longfellow" (15). Unlike the Specimen Days article, where he is careful not to discriminate between the four poets, he claims that "Emerson is by far the greatest of American authors" (22), and he chastises the others for their inability to capture the "strength and rankness" of human nature.

11 In Whitman the Political Poet, Erkkila locates the difference between the two theories of culture in Whitman's embrace of democracy and his challenge to the hegemonic dominance of an elite class, a class Arnold embraced as the preserver of cultural authority: Whitman's essay is "a full-scale attack on the genteel as a system of power no less class based than the feudal products of Europe." Where Erkkila focuses her attention on the political implications of Whitman's stance, Trachtenberg examines Whitman's interest in re-defining the word "culture," as well as the related concepts of "democracy" and "America." For Trachtenberg, the key issue is not the aristocratic legacy of feudalism, but rather the word "culture" itself, one which Whitman wishes to preserve for his own purposes: "His rage against 'the word Culture' is a rage against what he considers a fatal flaw in the prevailing definition, especially with its colonial mentality, its self-abasement before a sanctified Old World tradition" ("American Studies as a Cultural Program," in Walter Benn Michaels and Donald Pease, eds., American Renaissance Reconsidered [Baltimore: Johns Hopkins University Press, 1985], 175). For yet another comparison of Whitman and Arnold, see Robert Weisbuch, Atlantic Double-Cross: American Literature and British Influence in the Age of Emerson (Chicago: University of Chicago Press, 1986), 83-108.

12 The Theory of the Leisure Class (New York: Penguin, 1979), 391.

13 Literary Democracy: The Declaration of Cultural Independence (New York: Viking, 1981), 58-59.

14 The Autocrat of the Breakfast Table (New York: Sagamore Press, 1957), 244.

15 Interestingly, Holmes's satirical portrait, though written from the "inside" position of social privilege, corresponds in some respects to Whitman's own feelings toward the inner circle of Boston intellectuals and writers. Holmes disparages in his own "aristocracy" a "cheap dandyism" corresponding to a lack of "manhood" and "gallantry"; Whitman will likewise accuse Emerson of a "dandyfied theory of manners." 